\title{
Reaction of a Polyphosphino Ruthenium(II) Acetate Complex with Grignard Reagents: Halogenation, Alkylation and $\beta$ - Elimination
}

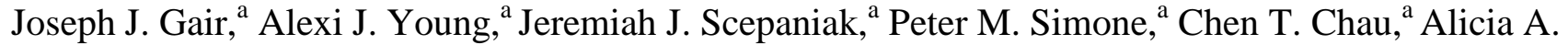 \\ Peterson, ${ }^{\mathrm{a}}$ Elizabeth M. Nesset Ferguson, ${ }^{\mathrm{a}}$ Williamson N. Oloo, ${ }^{\mathrm{a}}$ Daniel T. Welna, ${ }^{\mathrm{a}}$ Jonathan I. \\ Siverson, ${ }^{a}$ Lothar M. Stahl ${ }^{\mathrm{b}}$ and Chris P. Schaller ${ }^{\mathrm{a}}{ }^{*}$ \\ ${ }^{\mathrm{a}}$ Department of Chemistry, College of Saint Benedict/Saint John's University, St. Joseph, MN 56374 \\ ${ }^{\mathrm{b}}$ Chemistry Department, University of North Dakota, Grand Forks, ND 58202-9024
}

*Corresponding Author. Tel: +1 320363 5312; fax: +1 320363 5489. E-mail address: cschaller@ csbsju.edu (C. Schaller).

\begin{abstract}
:
$\left(\mathrm{PMe}_{3}\right)_{4} \mathrm{Ru}(\mathrm{H}) \mathrm{OAc}$ has been prepared from $\left(\mathrm{PPh}_{3}\right)_{3} \mathrm{Ru}(\mathrm{H}) \mathrm{OAc}$ via phosphine exchange followed by solvent partitioning between acetonitrile and pentane. Complexes of the type $\left(\mathrm{PMe}_{3}\right)_{4} \mathrm{Ru}(\mathrm{H}) \mathrm{R}\left(\mathrm{R}=\mathrm{Et},{ }^{n} \mathrm{Pr},{ }^{n} \mathrm{Bu},{ }^{i} \mathrm{Bu}, \mathrm{H}\right)$ have been synthesized through reaction with the corresponding Grignard reagents, $\mathrm{RMgCl}$, and were found to be moderately stable provided the alkyl group is primary. Treatment with bulkier alkylmagnesium chlorides led instead to the dihydrido complex $\left(\mathrm{PMe}_{3}\right)_{4} \mathrm{RuH}_{2}$. In some cases, the reaction

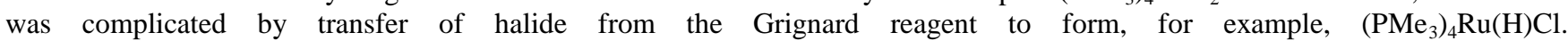

\section{Introduction}

Transition metal alkyl hydride complexes are critical intermediates in the activation of $\mathrm{C}-\mathrm{H}$ bonds through oxidative addition. ${ }^{1}$ These intermediates are also invoked in mechanistic schemes for a number of other processes, such as alkene hydrogenation and hydroformylation. ${ }^{2}$ Frequently, indirect evidence strongly suggests the presence of alkyl hydrides along a reaction pathway, most notably from studies showing $\mathrm{H} / \mathrm{D}$ exchange in hydrocarbons in the presence of transition metal complexes. ${ }^{3}$ These intermediates are infrequently observed because of their relative instability toward reductive elimination, beta-elimination and other reactions. The synthesis of alkyl hydride complexes is crucial to gain insight into the behavior of these elusive intermediates.

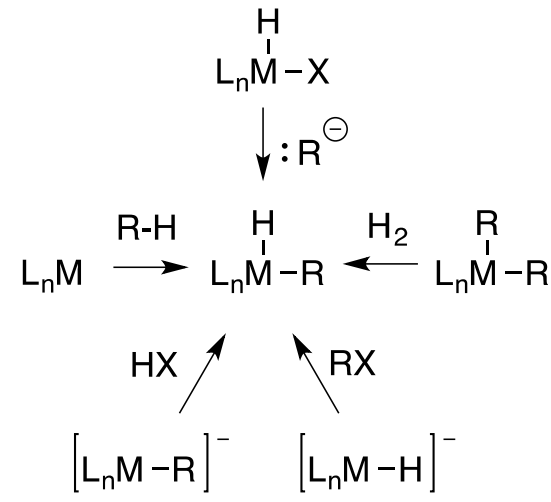

Scheme 1. Approaches to alkyl hydride complexes.
A number of methods have been applied to the synthesis of alkyl hydride complexes (Scheme 1). Direct synthesis via the oxidative addition of hydrocarbons may be the most germane approach given the principal focus on $\mathrm{C}-\mathrm{H}$ activation intermediates. This technique has been applied in a number of cases in which the resulting alkyl hydrides are particularly stable. $^{4}$ In some cases, polydentate ancillary ligands such as tris(pyrazolyl)borates or PNP-type pincer ligands stabilize these compounds by preventing ligand dissociation, ${ }^{5}$ as coordinative unsaturation is often required prior to reductive elimination. ${ }^{6}$ However, stable 16-electron complexes of this type have also been made in this way, as have relatively labile polyphosphino complexes. ${ }^{4 c, 6 b}$

Alkyl hydrides have also been prepared in less direct ways that do not involve oxidative addition. Protonation of metal alkyls is probably the most commonly used of these alternative techniques. ${ }^{7}$ This approach has been employed with square planar platinum(II) and iridium(I) alkyls; usually, the additional coordination by a counterion or by solvent results in an octahedral species. ${ }^{8}$ Octahedral alkyl hydride complexes have also been obtained via protonation of anionic fivecoordinate alkyls. ${ }^{9}$ In contrast, use of a non-coordinating counterion during protonation of a square planar iridium compound has allowed the isolation of a five-coordinate cationic species. $^{6 a}$

Other methods include hydrogenolysis of metal alkyls, accompanied by loss of alkane, ${ }^{10}$ the alkylation of hydride complexes containing labile anionic ligands, ${ }^{6 \mathrm{~b}, 9}$ and the treatment of anionic metal hydride complexes with alkyl triflates. $^{6 c}$ 
Significant attention has been paid to the study of the alkyl hydrides of $\mathrm{d}^{6}$ iridium(III) and platinum(IV), owing to the importance of $\mathrm{d}^{8}$ iridium(I) and platinum(II) complexes in carbon-hydrogen bond-cleaving events leading to alkane dehydrogenation and oxygenation, respectively. ${ }^{3 a}$ There have also been studies of $\mathrm{d}^{6}$ complexes of osmium(II) and ruthenium(II). ${ }^{4 c, 11}$ The latter cases deserve additional consideration because of the prominent role of ruthenium catalysts in synthetic organic reactions. ${ }^{12}$

We have undertaken synthetic studies leading to a series of different ruthenium alkyl hydrides, $\left(\mathrm{PMe}_{3}\right)_{4} \mathrm{Ru}(\mathrm{H}) \mathrm{R}(\mathbf{1 - R})$. Several compounds of this type have been synthesized previously, from the corresponding alkyl halides, ${ }^{13}$ hydrido halides, ${ }^{14}$ dihalides, ${ }^{15}$ or, in the case of $\mathbf{1 - P h}$, from the corresponding benzyne complex. ${ }^{11}$ Although some of these compounds have been reported previously, they have been prepared by disparate methods that do not lend themselves easily to the synthesis of new derivatives. A simplified synthetic scheme reported herein allow a variety of compounds to be prepared from a common synthetic intermediate. The result is an approach that provides selected ruthenium alkyl hydrides in three steps from commercially available materials.

\section{Results and discussion}

The goal of this work was to develop an easily accessible synthon that could be derivatized in one step to afford a variety of ruthenium alkyl hydrides. The polyphosphino compounds $\left(\mathrm{PMe}_{3}\right)_{4} \mathrm{Ru}(\mathrm{H}) \mathrm{R}(\mathbf{1 - R})$ were selected as synthetic targets. Some members of this family of compounds have previously been demonstrated to undergo reductive elimination to give alkanes at moderately elevated temperatures, and so it seemed reasonable that additional derivatives would also be relatively stable. ${ }^{11}$

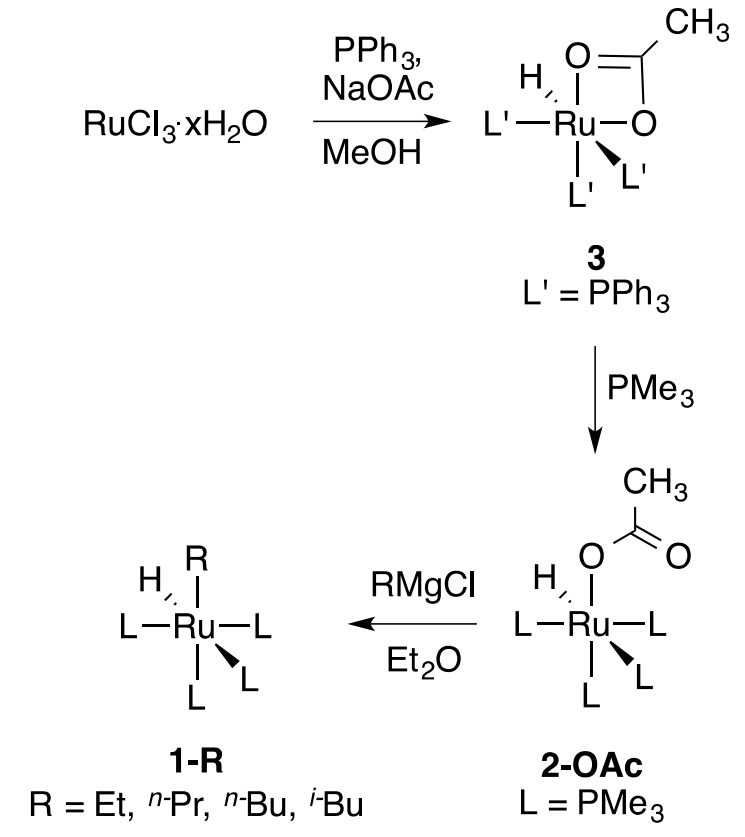

Scheme 2. A new approach to compounds 1-R.

Owing to the reported difficulty of working with the highly insoluble $\left(\mathrm{PMe}_{3}\right)_{4} \mathrm{Ru}(\mathrm{H}) \mathrm{Cl},{ }^{11}$ a similar synthon possessing an alternative labile, anionic ligand for displacement by alkylating agents was sought. One possibility was to use an acetate as a leaving group (Scheme 2). The triphenylphosphine complex, $\left(\mathrm{PPh}_{3}\right)_{3} \mathrm{Ru}(\mathrm{H}) \mathrm{OAc}(3)$, was easily prepared from commercially available materials, ${ }^{16}$ and replacement of the triphenylphosphine ligands with the more strongly donating trimethylphosphine was expected to afford 2-OAc.

Heating an orange slurry of $\mathbf{3}$ in toluene in the presence of excess trimethylphosphine quickly resulted in dissolution of solid and bleaching of the solution to a pale yellow color. Separation of 2-OAc from liberated triphenylphosphine at first proved challenging. Sublimation was fruitless, and attempts at recrystallization were stymied by co-crystallization of $\mathrm{PPh}_{3}$ with 2-OAc. A number of chromatographic approaches also failed; 2-OAc either failed to elute or else decomposed on the column. Solvent partitioning between acetonitrile and pentane produced more satisfactory results. Evaporation of the acetonitrile fraction produced almost quantitative yield of a waxy solid. ${ }^{1} \mathrm{H}$ NMR analysis revealed a downfield shift of the hydride resonance from $-18 \mathrm{ppm}$ observed in 3 to $-8.5 \mathrm{ppm}$ (See Appendix B). The complex splitting pattern of this hydride peak, an apparent doublet of quartets, and the 2:1:1 triplet:doublet:doublet $\mathrm{A}_{2} \mathrm{BC}$ pattern in the methyl region were consistent with $c i s$ - octahedral geometry. ${ }^{13}$ Further purification through recrystallization proved unreliable as trace amounts of triphenylphosphine remained in the samples.

The minor impurity in this material did not prevent its successful reaction with nucleophiles. Treatment of 2-OAc with $\mathrm{LiAlH}_{4}$ in THF led to formation of the dihydrido complex $\left(\mathrm{PMe}_{3}\right)_{4} \mathrm{RuH}_{2}$ (4, Scheme 3). Inspection of ${ }^{1} \mathrm{H}$ NMR data showed a triplet and doublet consistent with bound trimethylphosphine with an integration ratio $18: 18$ as well as an apparent doublet of triplets at $-9.73 \mathrm{ppm}$ integrating to 2 H. $^{17}$

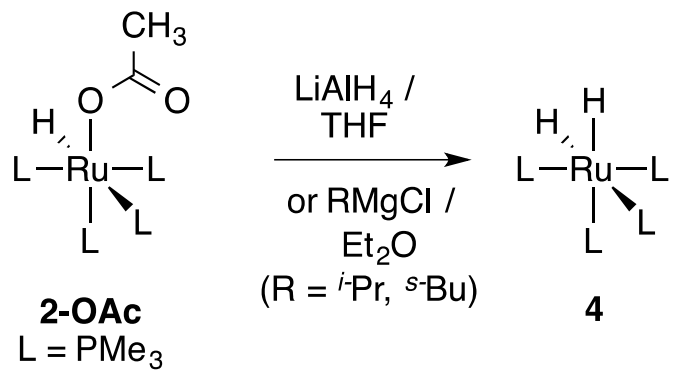

Scheme 3. New synthesis of $\left(\mathrm{PMe}_{3}\right)_{4} \mathrm{RuH}_{2}$.

The fact that saturated alkyl complexes (methyl, ethyl and propyl) had already been reported in this system suggested that targeting similar compounds would be a suitable next step for developing a general synthetic method. Longerchain alkyl ligands on transition metals are relatively rare because of their potential to undergo $\beta$-elimination. They have been reported in complexes with supporting tris(pyrazolyl)borate ligands, in which case the chelation effect probably hinders ligand dissociation required to open a coordination site for alkene complex formation. ${ }^{5}$ Examples have also been seen in early transition metal systems, as well as in systems in which $\pi$ donation from an ancillary ligand can stabilize an unsaturated metal center. ${ }^{18,19}$

Reaction of 2-OAc with alkylmagnesium chloride $\left(\mathrm{RMgCl} ; \mathrm{R}=\mathrm{Et},{ }^{n} \mathrm{Pr},{ }^{n} \mathrm{Bu},{ }^{i} \mathrm{Bu}\right)$ in diethyl ether resulted in substitution of the acetate ligand and formation of the corre sponding alkyl complexes (Scheme 4). Surprisingly, the reaction was not reproducible in THF, leading instead to the formation of intractable product mixtures. 
a)

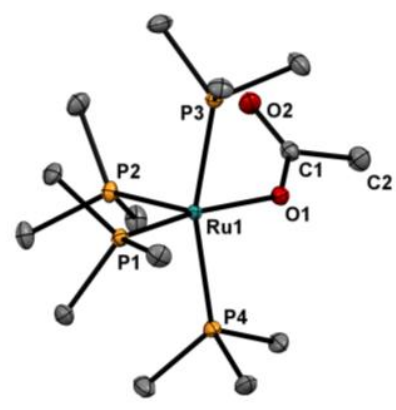

b)

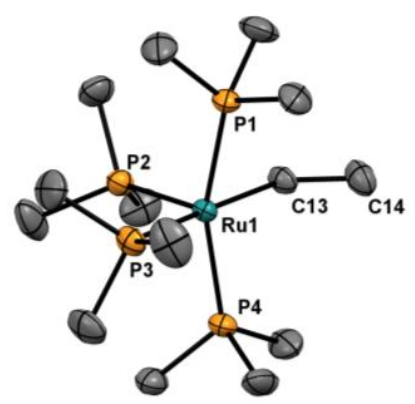

c)

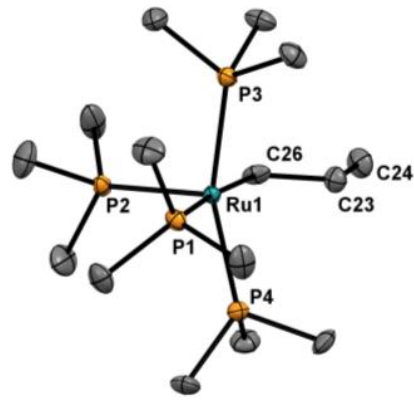

Figure 1. X-ray structure of (a) 2-OAc, (b) 1-Et and (c) 1-Pr. Selected bond distances ( $\mathrm{A}$ ) and angles (deg): (a) Ru1-O1 2.1721(11); Ru1-P1 2.2496(5); Ru1-P2 2.3756(5); Ru1-P4 2.3296(5); O1-Ru1-P1 170.32(3); P3-Ru1-P4 161.232(15). (b) Ru1-C13 2.214(3); Ru1P3 2.3200(8); Ru1-P2 2.3263(8); Ru1-P4 2.3149 (7) C13-Ru1-P3 174.76(8); P1-Ru1-P4 160.11(3). (c) Ru1-C26 2.206(3); Ru1-P1 2.3162(8); Ru1-P2 2.3354(9); Ru1-P4 2.3157(9); C26-Ru1-P1 174.99(8); P3-Ru1-P4 160.12(3).

In each of the alkyls 1-R, analysis of the ${ }^{1} \mathrm{H}$ NMR spectrum again revealed a characteristic triplet:doublet:doublet pattern for the ancillary trimethylphosphine ligand set in a cis-octahedral geometry. The peak corresponding to the acetyl group near $2.5 \mathrm{ppm}$ had disappeared, indicating displacement of the acetate ligand. The alkyl ligands proved harder to assign. In the case of the ethyl, broad multiplets at 1.86 and $0.76 \mathrm{ppm}$ were present in a $2: 3$ integration ratio compared to the hydride peak. Analogous peaks were also observed in the propyl, isobutyl and butyl complexes, corresponding to the methyl group and the methylene group attached to the metal center. Assignment of resonances for the other methylene hydrogens proved difficult, presumably because of overlap with the much more intense $\mathrm{PMe}_{3}$ peaks. However, interpretation was assisted by COSY assignments (see Appendix B). In addition to the spectral features outlined above, the hydride resonance, still an apparent doublet of quartets, had shifted upfield near $-9.5 \mathrm{ppm}$ in $\mathbf{1 - R}(\mathrm{R}=\mathrm{Et}$, $\left.{ }^{n} \mathrm{Pr},{ }^{n} \mathrm{Bu},{ }^{i} \mathrm{Bu}\right)$, as seen in related compounds. ${ }^{11}$

Single-crystal x-ray analysis of 1-OAc, 1-Et and 1- ${ }^{n} \mathbf{P r}$ provided solid-state structures consistent with the proposed structures in solution (Figure 1). The structure of 1-Et has been published previously, ${ }^{15}$ as well as the related dihydride $4 .^{20}$ In each case, the hydride ligand appears to exert a greater trans influence compared to the alkyl and the phosphines (Ru1-P2 = 2.3756(5) $\AA$ in 1-OAc, 2.3263(8) $\AA$ in 1-Et and 2.3354(9) $\AA$ in 1-Pr). All three structures display a steric compression towards the smaller hydride (e.g. P3-Ru1-P4 = 161.232(15) degrees in 1-OAc).

In contrast to the findings with primary alkylmagnesium reagents, treatment of $\mathbf{2 - O A c}$ with secondary alkylmagnesium chloride reagents $\left(\mathrm{RMgCl}, \mathrm{R}={ }^{i} \mathrm{Pr},{ }^{s} \mathrm{Bu}\right)$ did not lead to the direct observation of alkyl complexes. Instead, the dihydride complex 4 was observed (Scheme 5). Presumably, this compound resulted from formation of the respective alkyl complexes followed by immediate $\beta$ elimination of propene, 1-butene or 2-butene. The inability to observe these complexes is consistent with the trend that more sterically demanding alkyl ligands undergo $\beta$ elimination more rapidly. ${ }^{21}$ Other reports have suggested that there is a preference for less-substituted alkyl ligands based on anion stabilities, ${ }^{22}$ although C-H vs. C-M bond strengths play a key role in equilibria between isomeric alkyls. ${ }^{23}$ However, stable complexes of tertiary alkyl ligands have been reported before, including $t$-butyl and the even more sterically demanding adamantyl. ${ }^{24}$

The $n$-alkyl complexes, on the other hand, displayed moderate stability with respect to $\beta$-elimination. Solutions of 1Et and 1- ${ }^{\mathrm{n}} \mathrm{Pr}$ in $\mathrm{C}_{6} \mathrm{D}_{6}$ resisted $\beta$-elimination at $25^{\circ} \mathrm{C}$ for up to 12 hours, although heating to between 60 and $80{ }^{\circ} \mathrm{C}$ led to complex mixtures of decomposition products. Similarly, a solution of $1-^{i} \mathbf{B u}$ or $1-{ }^{n} \mathbf{B u}$ in deuterobenzene decomposed within 12 hours at $25{ }^{\circ} \mathrm{C}$ to give a mixture that displayed several different resonances in the hydride region. These complex mixtures could not be explained simply by $\beta$ elimination or isomerization to other alkyls, leading to the possibility that other processes are at work, although the role of minor impurities in decomposition cannot be ruled out. All four compounds, 1-Et, 1- ${ }^{n} \mathbf{P r}, 1-{ }^{i} \mathbf{B u}$ and $1-^{n} \mathbf{B u}$, underwent $\beta$-elimination at ambient temperature in the solid state over a period of several months, eventually forming 4 .

It should be noted that alkylmagnesium bromide and alkylmagnesium iodide reagents were not successful in alkylating 2-OAc. In those cases, product mixtures proved difficult to analyze. However, an independent synthesis of the iodo complex 2-I via treatment of 2-OAc with sodium iodide provided spectroscopic support for the formation of 2-I during alkylation with alkylmagnesium iodide. The appearance of a hydride peak in the ${ }^{1} \mathrm{H}$ NMR spectrum at $-17.8 \mathrm{ppm}$ was diagnostic for the presence of the iodo complex. A similar confirmation was attempted with an alternative synthesis of the presumed 2-Br, but in that case a pure product could not be isolated. 
<smiles>[3H][Te](I)(I)(I)OC(C)=O</smiles>

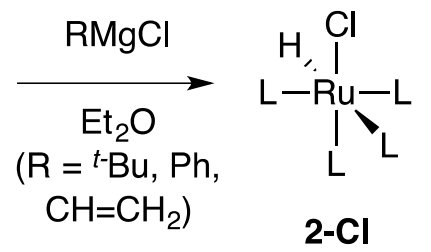

$\mathrm{L}=\mathrm{PMe}_{3}$

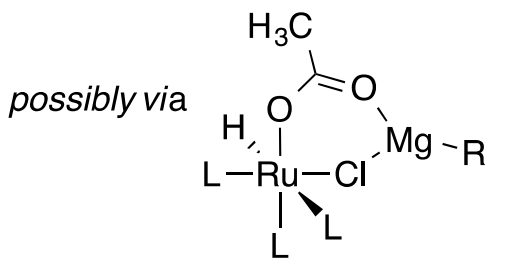

Scheme 4. Formation of $\left(\mathrm{PMe}_{3}\right)_{4} \mathrm{Ru}(\mathrm{H}) \mathrm{Cl}$.

In addition, the product of the reaction of 2-OAc with vinylmagnesium chloride failed to show evidence of a vinyl group in the ${ }^{1} \mathrm{H}$ NMR spectrum. Analysis of the product by ${ }^{1} \mathrm{H}$ NMR spectroscopy indicated that the acetate ligand had been displaced, leaving the phosphines and hydride ligand intact. Elemental analysis was consistent with $\left(\mathrm{PMe}_{3}\right)_{4} \mathrm{Ru}(\mathrm{H}) \mathrm{Cl}(\mathbf{2}-\mathrm{Cl})$. It appears that halogen transfer occurs in this case rather than the usual alkylation (Scheme 4). This phenomenon has been observed previously in other systems. ${ }^{25}$ Similar results were also observed after treatment of 2-OAc with $\mathrm{PhMgCl}$ and ${ }^{t} \mathrm{BuMgCl}$. It is unclear why halide exchange might occur in these reactions, but not in the case of the other Grignard reagents, although it may be that stronger carbon-magnesium bonds, in the case of the vinyl and phenyl compounds, retard donation of the hydrocarbon nucleophile to the metal. Presumably, the tert-butyl presents sufficient steric hindrance during the reaction that the chloride is transferred instead.

Neither of the halide complexes, 2-Cl or 2-I, proved viable starting materials for alkylation because of their limited solubility in ethereal solvents. This observation is consistent with previous reports. ${ }^{11 \mathrm{a}}$ The formation of bridging species may be a complicating factor in the behavior of these compounds. ${ }^{13}$

Halogen transfer may be a more pronounced factor during the use of alkylmagnesium bromides and iodides with 2-OAc compared to alkylmagnesium chlorides, since in the former cases the more strongly $\sigma$-donating halogen would be more susceptible to exchange. A thermodynamic preference for ruthenium iodide bonds over bonds with harder halides has been demonstrated. ${ }^{26}$ Furthermore, the failure of alkylation reactions to occur in THF may also be related to the halogen exchange problem. Grignard reagents have been shown to aggregate more strongly in diethyl ether solution than in THF, and it is possible that aggregation prevents halogens from being available to bind to the metal. ${ }^{27}$ Solventdependence in the reactivity of related organolithium compounds also provide ample precedent for the role of aggregation effects. ${ }^{28}$ However, it must be noted that halogen exchange among Grignard reagents is mechanistically very complicated, with a number of different routes to be considered. These pathways include the formation of ate complexes as well as single electron transfer. ${ }^{29}$ Alkylation of transition metals involving Grignard reagents has similarly been demonstrated to involve complex equilibria. ${ }^{30}$

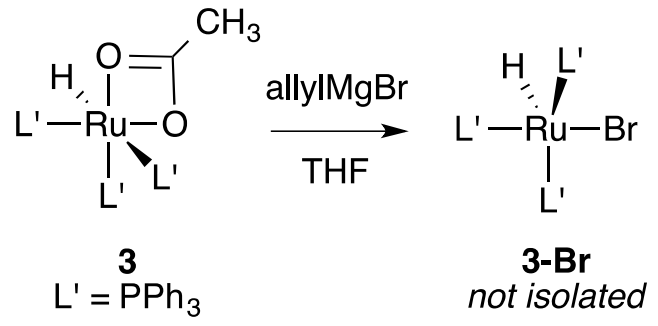

Scheme 5. Formation of $\left(\mathrm{PPh}_{3}\right)_{3} \mathrm{Ru}(\mathrm{H}) \mathrm{Br}$.

In an attempt to explore variations on this chemistry, the tris(triphenylphosphine) complex $\mathbf{3}$ was treated with Grignard reagents. Given that replacement of the acetate ligand on 3 with a monodentate alkyl group would result in a 16-electron complex, the reaction with allylmagnesium bromide was attempted. The alkylation reaction was not successful, but the product of the reaction was purple, consistent with $\left(\mathrm{PPh}_{3}\right)_{3} \mathrm{Ru}(\mathrm{H}) \mathrm{Br}\left(\mathbf{3}-\mathrm{Br}\right.$, Scheme 5). ${ }^{31}$ However, the poor solubility of 3-Br in hydrocarbon solvents hindered the isolation of a pure product from the accompanying magnesium salts. Similar changes in color were observed when 3 was treated with allylmagnesium chloride or iodide, but attempts to isolate pure compounds from the reaction mixture were equally fruitless in these cases. Nevertheless, further evidence for their formation was gained by refluxing product mixtures in hexanes in the presence of trimethylphosphine, leading to the appearance of peaks in hydride region of the ${ }^{1} \mathrm{H}$ NMR spectrum consistent with 2-Cl and 2-I. However, analytically pure samples could not be obtained with compounds 3-Cl or 3-I.

\section{Conclusion}

Alkyl hydrido polyphosphino ruthenium complexes of the type $\left(\mathrm{PMe}_{3}\right)_{4} \mathrm{Ru}(\mathrm{H}) \mathrm{R}$ have been prepared and were found to be moderately stable provided the alkyl group is primary. These compounds have been isolated despite the absence of multidentate ligands that would otherwise limit dissociation to form a vacant coordination site prior to a $\beta$-elimination step. On the other hand, it is presumed that the formation of secondary and tertiary alkyl complexes led to rapid decomposition of the compounds via $\beta$-elimination to give the dihydrido complex $\left(\mathrm{PMe}_{3}\right)_{4} \mathrm{RuH}_{2}$. This synthetic approach appears to be limited by competing halide transfer from the Grignard reagent. However, we speculate that the choice of both the solvent and the halide in the organomagnesium reagent may be useful in limiting this type of complication in other systems.

\section{Experimental section}

\section{General Considerations}

Unless otherwise noted, all reactions were carried out under a nitrogen or argon atmosphere using standard Schlenk or vacuum line techniques or in an inert atmosphere drybox. Reagents were purchased from Aldrich and used as received. Ethereal and aromatic solvents were dried over sodium with benzophenone indicator, then distilled before use. Saturated hydrocarbon solvents were dried over sodium with benzophenone indicator and tetraglyme, then distilled before 
use. However, it was also found that satisfactory results were obtained with anhydrous solvents in Sure/Seal bottles purchased directly from Aldrich, degassed and stored in an inert atmosphere drybox. $\left(\mathrm{PPh}_{3}\right)_{3} \mathrm{Ru}(\mathrm{H}) \mathrm{OAc}(3)$ was prepared as previously described. ${ }^{16} \mathrm{NMR}$ spectra were obtained on a JEOL $400 \mathrm{MHz}$ spectrometer using $\mathrm{C}_{6} \mathrm{D}_{6}$ that was dried over sodium and benzophenone before distilling. Infrared spectra of solid samples were obtained by attenuated total reflectance using a Nicolet 380 FTIR from Thermo Electron Corporation. Elemental Analyses were provided by H. Kolbe Mikroanalytisches Laboratorium, Mullheim an der Ruhr, Germany or by Atlantic Microlabs, Atlanta, GA.

\section{Experimental Procedures}

$\left(\mathrm{PMe}_{3}\right)_{4} \mathrm{Ru}(\mathrm{H}) \mathrm{OAc}(\mathbf{2 - O A c})$ :

$\left(\mathrm{PPh}_{3}\right)_{3} \mathrm{Ru}(\mathrm{H}) \mathrm{OAc}(2.70 \mathrm{~g}, 2.84 \mathrm{mmol})$ and toluene $(30 \mathrm{~mL})$ were loaded into a $250 \mathrm{~mL}$ pressure flask with vacuum connection to give an orange slurry. Trimethylphosphine $(2.40$ $\mathrm{mL}, 1.76 \mathrm{~g}, 8.0 \mathrm{eq}$ ) was added under nitrogen counterflow and the system was degassed via freeze-pump-thaw cycles $(3 \mathrm{x})$. The resulting yellow-green solution was submerged in an immersion circulator at $80{ }^{\circ} \mathrm{C}$ for one hour and concentrated in vacuo to yield a yellow-orange, waxy solid. The solid was dissolved in acetonitrile $(20 \mathrm{~mL})$ and washed with pentane $(5 \times 10 \mathrm{~mL})$ in an inert atmosphere glovebox. The acetonitrile solution was concentrated and the resulting waxy, yellow-green solid was recrystallized in a minimum of diethyl ether, then cooled to $-35{ }^{\circ} \mathrm{C}$ to give pale yellow crystals (1.30 g, $1.33 \mathrm{mmol}, 47 \%) .{ }^{1} \mathrm{H}$ NMR (400 MHz, $\left.\mathrm{C}_{6} \mathrm{D}_{6}\right): \delta$ [ppm] $2.20\left(\mathrm{~s}, 3 \mathrm{H},(\mathrm{CO}) \mathrm{CH}_{3}\right) ; 1.35(\mathrm{t}, J=2.9 \mathrm{~Hz}, 18 \mathrm{H}$, $\left.\mathrm{P}\left(\mathrm{CH}_{3}\right)_{3}\right) ; 1.26\left(\mathrm{~d}, J=5.8 \mathrm{~Hz}, 9 \mathrm{H}, \mathrm{P}\left(\mathrm{CH}_{3}\right)_{3}\right) ; 0.98(\mathrm{~d}, J=6.8$ $\left.\mathrm{Hz}, 9 \mathrm{H}, \mathrm{P}\left(\mathrm{CH}_{3}\right)_{3}\right) ;-8.42(\mathrm{dq}, J=101.1 \mathrm{~Hz}, 27.5 \mathrm{~Hz}, 1 \mathrm{H}$, $\mathrm{RuH}) .{ }^{13} \mathrm{C}\left\{{ }^{1} \mathrm{H}\right\}$ NMR $\left(100 \mathrm{MHz}, \mathrm{C}_{6} \mathrm{D}_{6}\right): \delta[\mathrm{ppm}] 175.9(\mathrm{~m}$, $\mathbf{C}=\mathrm{O}), 26.4\left(\mathrm{~d}, J=26.4 \mathrm{~Hz}, \mathrm{P}\left(\mathrm{CH}_{3}\right)_{3}\right), 22.9(\mathrm{t}, J=14.2 \mathrm{~Hz}$, $\left.\mathrm{P}\left(\mathrm{CH}_{3}\right)_{3}\right), 22.3\left(\mathrm{~d}, J=16.9 \mathrm{~Hz}, \mathrm{P}\left(\mathrm{CH}_{3}\right)_{3}\right) .{ }^{31} \mathrm{P} \mathrm{NMR}(162$ $\left.\mathrm{MHz}, \mathrm{C}_{6} \mathrm{D}_{6}\right): \delta[\mathrm{ppm}] 0.01(\mathrm{~m}),-11.58(\mathrm{~m}), \quad-12.32(\mathrm{~m})$. IR: v (cm $\left.{ }^{-1}\right) 2903(\mathrm{~m}), 1806(\mathrm{~s}, \mathrm{Ru}-\mathrm{H}), 1597$ (s, C=O), 1376 (m), 1297 (m), 1275 (m), 934 (s), 854 (m), 749 (w), 698 (m), 664 (m). Anal. Calcd. for $\mathrm{C}_{14} \mathrm{H}_{40} \mathrm{P}_{4} \mathrm{O}_{2} \mathrm{Ru}$ : C, 36.16; H, 8.66; $\mathrm{P}$, 26.62. Found: C, 37.99; H, 8.54; P: 25.76.

\section{$\left(\mathrm{PMe}_{3}\right)_{4} \mathrm{Ru}(\mathrm{H}) \mathrm{CH}_{2} \mathrm{CH}_{3}(\mathrm{l}-\mathrm{Et})$ :}

$\left(\mathrm{PMe}_{3}\right)_{4} \mathrm{Ru}(\mathrm{H}) \mathrm{OAc}(500 \mathrm{mg}, 1.08 \mathrm{mmol})$ was dissolved in diethyl ether $(10 \mathrm{~mL})$ in a $25 \mathrm{~mL}$ round bottom flask attached to a needle valve. The pale yellow solution was cooled to -78 ${ }^{\circ} \mathrm{C}$ and $\mathrm{EtMgCl}\left(2.0 \mathrm{M}\right.$ in $\left.\mathrm{Et}_{2} \mathrm{O}, 0.59 \mathrm{~mL}, 1.18 \mathrm{mmol}\right)$ was syringed into the solution under nitrogen counterflow. The cold bath was slowly allowed to warm to ambient temperature and the white slurry was stirred for an additional hour before removing the ether in vacuo. The off-white, solid residue was extracted with heptane $(3 \times 10 \mathrm{~mL})$, filtered, and the heptane was removed in vacuo to afford a white solid (336 mg, $0.78 \mathrm{mmol}, 72 \%$ ). X-ray quality crystals were obtained via recrystallization from toluene. ${ }^{1} \mathrm{H}$ NMR (400 $\left.\mathrm{MHz}, \mathrm{C}_{6} \mathrm{D}_{6}\right): \delta[\mathrm{ppm}] 1.86\left(\mathrm{~m}, 3 \mathrm{H}, \mathrm{CH}_{2} \mathrm{CH}_{3}\right), 1.35$ (t, $J=2.5$ $\left.\mathrm{Hz}, 18 \mathrm{H}, \mathrm{P}\left(\mathrm{CH}_{3}\right)_{3}\right), 1.21\left(\mathrm{~d}, J=5.6 \mathrm{~Hz}, 9 \mathrm{H}, \mathrm{P}\left(\mathrm{CH}_{3}\right)_{3}\right), 1.05$ $\left(\mathrm{d}, J=5.4 \mathrm{~Hz}, 9 \mathrm{H}, \mathrm{P}\left(\mathrm{CH}_{3}\right)_{3}\right), 0.76\left(\mathrm{~m}, 2 \mathrm{H}, \mathrm{CH}_{2} \mathrm{CH}_{3}\right),-9.79$ (ddt, $J=105.7 \mathrm{~Hz}, 30.6 \mathrm{~Hz}, 17.7 \mathrm{~Hz}, 1 \mathrm{H}, \mathrm{Ru}-\mathbf{H}) .{ }^{13} \mathrm{C}\left\{{ }^{1} \mathrm{H}\right\}$ NMR (100 MHz, $\left.\mathrm{C}_{6} \mathrm{D}_{6}\right): \delta[\mathrm{ppm}] 28.58\left(\mathrm{~m}, \mathrm{P}\left(\mathrm{CH}_{3}\right)_{3}\right), 27.81$ (d, $J=11.6 \mathrm{~Hz}, \mathrm{CH}_{2} \mathrm{CH}_{3}$ ), 24.91 (tt, $J=12.4 \mathrm{~Hz}, 3.4 \mathrm{~Hz}$, $\left.\mathrm{P}\left(\mathrm{CH}_{3}\right)_{3}\right), 22.89\left(\mathrm{dq}, J=14.3 \mathrm{~Hz}, 3.0 \mathrm{~Hz}, \mathrm{P}\left(\mathbf{C H}_{3}\right)_{3}\right), 0.25(\mathrm{~m}$, $\left.\mathrm{CH}_{2} \mathrm{CH}_{3}\right) .{ }^{31} \mathrm{P}$ NMR (162 MHz, $\left.\mathrm{C}_{6} \mathrm{D}_{6}\right): \delta[\mathrm{ppm}] 0.05(\mathrm{~m})$, $-11.65(\mathrm{~m}), \quad-12.33(\mathrm{~m})$. IR: v $\left(\mathrm{cm}^{-1}\right) 3002(\mathrm{~m}), 1811(\mathrm{~m}, \mathrm{Ru}-$ $\mathrm{H}), 1475(\mathrm{~m}), 1308(\mathrm{~m}), 1278(\mathrm{~m}), 940$ (m), $858(\mathrm{~m}), 740$ (m), $690(\mathrm{~m})$. Analysis calculated for $\mathrm{C}_{14} \mathrm{H}_{42} \mathrm{P}_{4} \mathrm{Ru}(\%)$ : C, 38.80; H, 9.77; P, 28.58. Found: C, 38.88; H, 9.80; P: 28.51.

\section{$\left(\mathrm{PMe}_{3}\right)_{4} \mathrm{Ru}(\mathrm{H}) \mathrm{CH}_{2} \mathrm{CH}_{2} \mathrm{CH}_{3}\left(\mathrm{l}-{ }^{n} \mathrm{Pr}\right)$ :}

The procedure for 1-Et was followed using $\left(\mathrm{PMe}_{3}\right)_{4} \mathrm{Ru}(\mathrm{H}) \mathrm{OAc}(440 \mathrm{mg}, 0.95 \mathrm{mmol})$ and ${ }^{n} \mathrm{PrMgCl}(2.0$ $\mathrm{M}$ in $\left.\mathrm{Et}_{2} \mathrm{O}, 0.52 \mathrm{~mL}, 1.04 \mathrm{mmol}\right)$. Recrystallization from heptane at $-78{ }^{\circ} \mathrm{C}$ yielded a white, semi-crystalline solid (275 $\mathrm{mg}, 0.62 \mathrm{mmol}, 65 \%)$. ${ }^{1} \mathrm{H} \mathrm{NMR}\left(400 \mathrm{MHz}, \mathrm{C}_{6} \mathrm{D}_{6}\right): \delta$ [ppm] $1.87\left(\mathrm{~m}, 2 \mathrm{H}, \mathrm{CH}_{2} \mathrm{CH}_{2} \mathrm{CH}_{3}\right), 1.32(\mathrm{t}, J=2.5 \mathrm{~Hz}, 18 \mathrm{H}$, $\left.\mathrm{P}\left(\mathrm{CH}_{3}\right)_{3}\right), 1.30\left(\mathrm{t}, J=6.7 \mathrm{~Hz}, 3 \mathrm{H}, \mathrm{CH}_{2} \mathrm{CH}_{2} \mathrm{CH}_{3}\right), 1.20(\mathrm{~d}, J=$ $\left.4.9 \mathrm{~Hz}, 9 \mathrm{H}, \mathrm{P}\left(\mathrm{CH}_{3}\right)_{3}\right) 1.05\left(\mathrm{~d}, J=4.9 \mathrm{~Hz}, 9 \mathrm{H}, \mathrm{P}\left(\mathrm{CH}_{3}\right)_{3}\right), 0.63$ $\left(\mathrm{m}, 2 \mathrm{H}, \mathrm{CH}_{2} \mathrm{CH}_{2} \mathrm{CH}_{3}\right.$ ), -9.84 (ddt, $J=100.5 \mathrm{~Hz}, 32.0 \mathrm{~Hz}$, $15.6 \mathrm{~Hz}, 1 \mathrm{H}, \mathrm{Ru}-\mathrm{H}) .{ }^{13} \mathrm{C}\left\{{ }^{1} \mathrm{H}\right\} \mathrm{NMR}\left(100 \mathrm{MHz}, \mathrm{C}_{6} \mathrm{D}_{6}\right): \delta$ [ppm] 36.99 (d, $\left.J=13.2 \mathrm{~Hz}, \mathrm{CH}_{2} \mathrm{CH}_{2} \mathrm{CH}_{3}\right), 26.02$ (d, $J=16.9$ $\left.\mathrm{Hz}, \mathrm{P}\left(\mathbf{C H}_{3}\right)_{3}\right), 24.66\left(\mathrm{t}, J=12.9 \mathrm{~Hz}, \mathrm{P}\left(\mathbf{C H}_{3}\right)_{3}\right), 22.94(\mathrm{~d}, J=$ $\left.14.2 \mathrm{~Hz}, \mathrm{P}\left(\mathrm{CH}_{3}\right)_{3}\right), 22.52$ (d, $\left.J=8.3 \mathrm{~Hz}, \mathrm{CH}_{2} \mathrm{CH}_{2} \mathbf{C H}_{3}\right), 13.05$ $\left(\mathrm{m}, \mathrm{CH}_{2} \mathrm{CH}_{2} \mathrm{CH}_{3}\right) .{ }^{31} \mathrm{P}$ NMR $\left(162 \mathrm{MHz}, \mathrm{C}_{6} \mathrm{D}_{6}\right): \delta[\mathrm{ppm}]$ $-0.25(\mathrm{~m}),-11.63(\mathrm{~m}), \quad-13.05(\mathrm{~m})$. IR: $v\left(\mathrm{~cm}^{-1}\right) 2899(\mathrm{~m})$, 1801 (m, Ru-H) , 1292 (m), 924 (s), 696 (s), 657 (s). Analysis calculated for $\mathrm{C}_{15} \mathrm{H}_{44} \mathrm{P}_{4} \mathrm{Ru}(\%)$ : C, 40.08; H, 9.87. Found: $\mathrm{C}$, 40.82; H, 9.88.

\section{$\left(\mathrm{PMe}_{3}\right)_{4} \mathrm{Ru}(\mathrm{H}) \mathrm{CH}_{2} \mathrm{CH}\left(\mathrm{CH}_{3}\right)_{2}\left(\mathbf{1}^{i} \mathrm{~B} \boldsymbol{B}\right):$}

The procedure for 1-Et was followed using $\left(\mathrm{PMe}_{3}\right)_{4} \mathrm{Ru}(\mathrm{H}) \mathrm{OAc}(410 \mathrm{mg}, 0.88 \mathrm{mmol})$ and iso-butyl magnesium chloride $\left(2.0 \mathrm{M}\right.$ in $\left.\mathrm{Et}_{2} \mathrm{O}, 0.49 \mathrm{~mL}, 0.98 \mathrm{mmol}\right)$. After extraction with heptane, the solution was evaporated to dryness to yield a very pale yellow solid, which was recrystallized from toluene at $-35^{\circ} \mathrm{C}$ to yield a white crystalline solid (0.21g, $0.47 \mathrm{mmol}, 53 \%) .{ }^{1} \mathrm{H}$ NMR (400 MHz, $\left.\mathrm{C}_{6} \mathrm{D}_{6}\right): \delta$ [ppm] $1.75\left(\mathrm{~m}, 1 \mathrm{H}, \mathrm{CH}_{2} \mathrm{CH}\left(\mathrm{CH}_{3}\right)_{2}\right), 1.48(\mathrm{~d}, J=6.8 \mathrm{~Hz}, 6 \mathrm{H}$, $\left.\mathrm{CH}_{2} \mathrm{CH}\left(\mathrm{CH}_{3}\right)_{2}\right), 1.30$ (t, $\left.J=2.4 \mathrm{~Hz}, 18 \mathrm{H}, \mathrm{P}\left(\mathrm{CH}_{3}\right)_{3}\right), 1.17$ (d, $J$ $\left.=4.7 \mathrm{~Hz}, 9 \mathrm{H}, \mathrm{P}\left(\mathrm{CH}_{3}\right)_{3}\right) 0.99\left(\mathrm{~d}, J=4.8 \mathrm{~Hz}, 9 \mathrm{H}, \mathrm{P}\left(\mathrm{CH}_{3}\right)_{3}\right)$, $0.77\left(\mathrm{~m}, 2 \mathrm{H}, \mathrm{CH}_{2} \mathrm{CH}\left(\mathrm{CH}_{3}\right)_{2}\right),-9.72(\mathrm{ddt}, J=83.4 \mathrm{~Hz}, 28.2$ $\mathrm{Hz}, 21.5 \mathrm{~Hz}, 1 \mathrm{H}, \mathrm{Ru}-\mathbf{H}) .{ }^{13} \mathrm{C}\left\{{ }^{1} \mathrm{H}\right\} \mathrm{NMR}\left(100 \mathrm{MHz}, \mathrm{C}_{6} \mathrm{D}_{6}\right): \delta$ [ppm] $35.22\left(\mathrm{~d}, J=7.3 \mathrm{~Hz}, \mathrm{CH}_{2} \mathrm{CH}\left(\mathrm{CH}_{3}\right)_{2}\right), 28.78(\mathrm{~d}, J=$ $\left.15.5 \mathrm{~Hz}, \mathrm{P}\left(\mathrm{CH}_{3}\right)_{3}\right), 27.97\left(\mathrm{~s}, \mathrm{CH}_{2} \mathrm{CH}\left(\mathrm{CH}_{3}\right)_{2}\right), 24.91$ (t, $J=$ $\left.12.8 \mathrm{~Hz}, \mathrm{P}\left(\mathrm{CH}_{3}\right)_{3}\right), 22.83\left(\mathrm{~d}, J=14.5 \mathrm{~Hz}, \mathrm{P}\left(\mathrm{CH}_{3}\right)_{3}\right), 19.32(\mathrm{~m}$, $\left.\mathrm{CH}_{2} \mathrm{CH}\left(\mathrm{CH}_{3}\right)_{2}\right)$. ${ }^{31} \mathrm{P}$ NMR $\left(162 \mathrm{MHz}, \mathrm{C}_{6} \mathrm{D}_{6}\right): \delta[\mathrm{ppm}] 0.17$ (m), -12.25 (m), -13.53 (m). IR: v $\left(\mathrm{cm}^{-1}\right) 2903(\mathrm{~m}), 1801(\mathrm{~m}$, $\mathrm{Ru}-\mathrm{H})$, 1276 (m), 929 (s), 725 (s), 663 (s). Analysis calculated for $\mathrm{C}_{16} \mathrm{H}_{46} \mathrm{P}_{4} \mathrm{Ru}(\%)$ : C, 41.46; H, 10.00. Found: $\mathrm{C}$, 45.68, 9.10.

\section{$\left(\mathrm{PMe}_{3}\right)_{4} \mathrm{Ru}(\mathrm{H}) \mathrm{CH}_{2} \mathrm{CH}_{2} \mathrm{CH}_{2} \mathrm{CH}_{3}\left(1-{ }^{n} \mathrm{Bu}\right):$}

The procedure for 1-Et was followed using $\left(\mathrm{PMe}_{3}\right)_{4} \mathrm{Ru}(\mathrm{H}) \mathrm{OAc} \quad(608 \mathrm{mg}, \quad 1.31 \quad \mathrm{mmol}) \quad$ and butylmagnesium chloride $\left(2.0 \mathrm{M}\right.$ in $\mathrm{Et}_{2} \mathrm{O}, 0.72 \mathrm{~mL}, 1.44$ mmol). After extraction with heptane, the solution was concentrated in vacuo and cooled to $-35{ }^{\circ} \mathrm{C}$ to yield pale yellow microcrystals (436 mg, $0.57 \mathrm{mmol}, 72 \%) .{ }^{1} \mathrm{H}$ NMR (400 $\left.\mathrm{MHz}, \mathrm{C}_{6} \mathrm{D}_{6}\right): \delta$ [ppm] $1.82\left(\mathrm{~m}, 2 \mathrm{H}, \mathrm{CH}_{2} \mathrm{CH}_{2} \mathrm{CH}_{2} \mathrm{CH}_{3}\right) ; 1.61$ $\left(\mathrm{m}, 2 \mathrm{H}, \mathrm{CH}_{2} \mathrm{CH}_{2} \mathrm{CH}_{2} \mathrm{CH}_{3}\right) ; 1.32(\mathrm{t}, J=2.3 \mathrm{~Hz}, 18 \mathrm{H}$, $\left.\mathrm{P}\left(\mathrm{CH}_{3}\right)_{3}\right) ; 1.20\left(\mathrm{~d}, J=5.3 \mathrm{~Hz}, 9 \mathrm{H}, \mathrm{P}\left(\mathrm{CH}_{3}\right)_{3}\right) ; 1.16$ (observed only via $\left.\mathrm{COSY}, \mathrm{CH}_{2} \mathrm{CH}_{2} \mathrm{CH}_{2} \mathrm{CH}_{3}\right) ; 0.99(\mathrm{~d}, J=5.1 \mathrm{~Hz}, 9 \mathrm{H}$, $\left.\mathrm{P}\left(\mathrm{CH}_{3}\right)_{3}\right) ; 0.56\left(\mathrm{~m}, 2 \mathrm{H}, \mathrm{CH}_{2} \mathrm{CH}_{2} \mathrm{CH}_{2} \mathrm{CH}_{3}\right) ;-9.82$ (ddt, $J=$ $85.9 \mathrm{~Hz}, 30.5 \mathrm{~Hz}, 17.1 \mathrm{~Hz}, 1 \mathrm{H}, \mathrm{Ru}-\mathrm{H}) .{ }^{13} \mathrm{C}\left\{{ }^{1} \mathrm{H}\right\}$ NMR $(100$ $\left.\mathrm{MHz}, \quad \mathrm{C}_{6} \mathrm{D}_{6}\right): \quad \delta \quad[\mathrm{ppm}] \quad 31.32 \quad(\mathrm{~d}, \quad J=8.4 \mathrm{~Hz}$, $\left.\mathrm{CH}_{2} \mathrm{CH}_{2} \mathrm{CH}_{2} \mathrm{CH}_{3}\right), \quad 28.45 \quad\left(\mathrm{~m}, \quad \mathrm{P}\left(\mathrm{CH}_{3}\right)_{3}\right), 25.13 \quad(\mathrm{~m}$, 
$\left.\mathrm{CH}_{2} \mathrm{CH}_{2} \mathrm{CH}_{2} \mathrm{CH}_{3}\right), 24.65$ (tt, $\left.J=12.3 \mathrm{~Hz}, 4.0 \mathrm{~Hz}, \mathrm{P}\left(\mathrm{CH}_{3}\right)_{3}\right)$, $22.97\left(\mathrm{dq}, J=17.3 \mathrm{~Hz}, 3.0 \mathrm{~Hz}, \mathrm{P}\left(\mathbf{C H}_{3}\right)_{3}\right), 14.73$ (s, $\mathrm{CH}_{2} \mathrm{CH}_{2} \mathrm{CH}_{2} \mathrm{CH}_{3}$ ), 14.06 (m, $\left.\mathrm{CH}_{2} \mathrm{CH}_{2} \mathrm{CH}_{2} \mathrm{CH}_{3}\right) .{ }^{31} \mathrm{P} \mathrm{NMR}$ $\left(162 \mathrm{MHz}, \mathrm{C}_{6} \mathrm{D}_{6}\right): \delta[\mathrm{ppm}] \quad-0.31(\mathrm{~m}),-11.60(\mathrm{~m}),-12.18$ (m). IR: v ( $\left.\mathrm{cm}^{-1}\right) 2905(\mathrm{~m}), 1803(\mathrm{~m}, \mathrm{Ru}-\mathrm{H}), 1293(\mathrm{~m}), 925$ (s), 695 (s), 656 (s). Analysis calculated for $\mathrm{C}_{16} \mathrm{H}_{46} \mathrm{P}_{4} \mathrm{Ru}(\%)$ : C, 41.46; H, 10.00. Found: C, 44.48, 9.51.

\section{$\left(\mathrm{PMe}_{3}\right)_{4} \mathrm{Ru}(\mathrm{H}) \mathrm{Cl}(\mathbf{2 - C l})$ :}

The procedure for 1-Et was followed using $\left(\mathrm{PMe}_{3}\right)_{4} \mathrm{Ru}(\mathrm{H}) \mathrm{OAc} \quad(450 \quad \mathrm{mg}, \quad 0.97 \quad \mathrm{mmol}) \quad$ and vinylmagnesium chloride $\left(1.6 \mathrm{M}\right.$ in $\mathrm{Et}_{2} \mathrm{O}, 0.67 \mathrm{~mL}, 1.07$ mmol). After extraction with heptane, the solution was concentrated in vacuo and cooled to $-35^{\circ} \mathrm{C}$ to yield pale yellow microcrystals (182 mg, $0.41 \mathrm{mmol}, 42 \%) .{ }^{1} \mathrm{H}$ NMR (400 $\left.\mathrm{MHz}, \mathrm{C}_{6} \mathrm{D}_{6}\right): \delta[\mathrm{ppm}] 1.43\left(\mathrm{t}, J=3.0 \mathrm{~Hz}, 18 \mathrm{H}, \mathrm{P}\left(\mathrm{CH}_{3}\right)_{3}\right), 1.14$ $\left(\mathrm{d}, J=5.5 \mathrm{~Hz}, 9 \mathrm{H}, \mathrm{P}\left(\mathrm{CH}_{3}\right)_{3}\right), 1.01(\mathrm{~d}, J=7.8 \mathrm{~Hz}, 9 \mathrm{H}$, $\left.\mathrm{P}\left(\mathrm{CH}_{3}\right)_{3}\right),-8.55(\mathrm{dq}, J=105.4 \mathrm{~Hz}, 28.8 \mathrm{~Hz}, 1 \mathrm{H}, \mathrm{Ru}-\mathbf{H}) .{ }^{13} \mathrm{C}$ $\left\{{ }^{1} \mathrm{H}\right\}$ NMR (100 MHz, $\left.\mathrm{C}_{6} \mathrm{D}_{6}\right): \delta[\mathrm{ppm}] 27.64\left(\mathrm{~m}, \mathrm{P}\left(\mathrm{CH}_{3}\right)_{3}\right)$, $23.26\left(\mathrm{dt}, J=13.6 \mathrm{~Hz}, 3.8 \mathrm{~Hz}, \mathrm{P}\left(\mathrm{CH}_{3}\right)_{3}\right), 21.69$ (dt, $J=16.4$ $\left.\mathrm{Hz}, 2.5 \mathrm{~Hz}, \mathrm{P}\left(\mathrm{CH}_{3}\right)_{3}\right) .{ }^{31} \mathrm{P} \mathrm{NMR}\left(162 \mathrm{MHz}, \mathrm{C}_{6} \mathrm{D}_{6}\right): \delta[\mathrm{ppm}]$ $17.52(\mathrm{~m}),-3.95(\mathrm{~m}), \quad-16.06(\mathrm{~m})$. IR: $v\left(\mathrm{~cm}^{-1}\right) 2901(\mathrm{~m})$, 1844 (m, Ru-H), 1432 (m), 1274 (m), 929 (s), 848 (m), 692 (m). Analysis calculated for $\mathrm{C}_{12} \mathrm{H}_{37} \mathrm{ClP}_{4} \mathrm{Ru}(\%)$ : C, 32.62; $\mathrm{H}$, 8.44. Found: C, 33.17, 8.40.

$\left(\mathrm{PMe}_{3}\right)_{4} \mathrm{Ru}(\mathrm{H}) \mathrm{I}(2-\mathrm{I})$ :

A Schlenk flask was charged with $\left(\mathrm{PMe}_{3}\right)_{4} \mathrm{Ru}(\mathrm{H}) \mathrm{OAc}(3.14$ $\mathrm{g}, 6.77 \mathrm{mmol})$ and sodium iodide $(1.01 \mathrm{~g}, 6.75 \mathrm{mmol})$. Addition of THF $(30 \mathrm{~mL})$ produced a wine-red slurry, which was refluxed under a nitrogen atmosphere for 2 hours. After removal of the solvent in vacuo, the solid residue was washed with hexane $(3 \times 10 \mathrm{~mL})$ and extracted with dichloromethane $(3 \times 10 \mathrm{~mL})$. The red dichloromethane filtrate was concentrated in vacuo to produce an orange solid (1.72 g, 3.24 mmol, 48\%). ${ }^{1} \mathrm{H}$ NMR (400 MHz, $\left.\mathrm{C}_{6} \mathrm{D}_{6}\right): \delta[\mathrm{ppm}] 1.42(\mathrm{~m}$, $\left.36 \mathrm{H}, \mathrm{P}\left(\mathrm{CH}_{3}\right)_{3}\right),-17.73$ (quint, $J=24.3 \mathrm{~Hz}, 1 \mathrm{H}, \mathrm{Ru}-\mathrm{H}$ ). ${ }^{13} \mathrm{C}$ $\left\{{ }^{1} \mathrm{H}\right\} \mathrm{NMR}\left(100 \mathrm{MHz}, \mathrm{C}_{6} \mathrm{D}_{6}\right): \delta[\mathrm{ppm}] 24.14\left(\mathrm{~m}, \mathrm{P}\left(\mathrm{CH}_{3}\right)_{3}\right)$. ${ }^{31} \mathrm{P}$ NMR $\left(162 \mathrm{MHz}, \mathrm{C}_{6} \mathrm{D}_{6}\right): \delta[\mathrm{ppm}]-8.58(\mathrm{~m})$. IR: v $\left(\mathrm{cm}^{-1}\right)$ 2909 (m), 1907 (m, Ru-H), 1417 (m), 1278 (m), 926 (s), 851 (m), $701(\mathrm{~m})$. Analysis calculated for $\mathrm{C}_{12} \mathrm{H}_{37} \mathrm{IP}_{4} \mathrm{Ru}(\%)$ : C, 27.0; H, 6.99. Found: C, 28.79, 6.37.

\section{$\left(\mathrm{PMe}_{3}\right)_{4} \mathrm{RuH}_{2}(4)$ :}

A $25 \mathrm{ml}$ three neck round bottom flask was charged with $\left(\mathrm{PMe}_{3}\right)_{4} \mathrm{Ru}(\mathrm{H}) \mathrm{OAc}(0.502 \mathrm{~g}, 1.08 \mathrm{mmol})$ and THF $(20 \mathrm{~mL})$ under nitrogen. A solid addition funnel was charged with $\mathrm{LiAlH}_{4}(0.041 \mathrm{~g}, 1.08 \mathrm{mmol})$ and connected to the three neck flask along with a needle valve. The reaction mixture was cooled to $-78^{\circ} \mathrm{C}$, the $\mathrm{LiAlH}_{4}$ was slowly added and the solution was stirred for 1 hour, warmed to room temperature and stirred for an additional 2 hours. The solvent was removed and the yellow residue was extracted with pentane $(5 \times 10$ $\mathrm{mL})$. The combined extracts were concentrated in vacuo, cooled to $-78{ }^{\circ} \mathrm{C}$ and filtered to obtain a yellow solid $(0.207$ $\mathrm{g}, 0.508 \mathrm{mmol}, 47 \%)$. ${ }^{1} \mathrm{H}$ NMR $\left(400 \mathrm{MHz}, \mathrm{C}_{6} \mathrm{D}_{6}\right): \delta[\mathrm{ppm}]$ $1.38\left(\mathrm{t}, J=2.6 \mathrm{~Hz}, 18 \mathrm{H}, \mathrm{P}\left(\mathrm{CH}_{3}\right)_{3}\right), 1.25(\mathrm{~d}, J=5.0 \mathrm{~Hz}, 18 \mathrm{H}$, $\left.\mathrm{P}\left(\mathrm{CH}_{3}\right)_{3}\right),-9.73(\mathrm{dt}, J=52.3 \mathrm{~Hz}, 31.0 \mathrm{~Hz}, 2 \mathrm{H}, \mathrm{Ru}-\mathrm{H}) .{ }^{13} \mathrm{C}$ $\left\{{ }^{1} \mathrm{H}\right\}$ NMR $\left(100 \mathrm{MHz}, \mathrm{C}_{6} \mathrm{D}_{6}\right): \delta[\mathrm{ppm}] 29.62(\mathrm{tt}, J=13.4 \mathrm{~Hz}$, $\left.4.3 \mathrm{~Hz}, \mathrm{P}\left(\mathrm{CH}_{3}\right)_{3}\right), 27.65\left(\mathrm{~m}, \mathrm{P}\left(\mathrm{CH}_{3}\right)_{3}\right)$. ${ }^{31} \mathrm{P} \mathrm{NMR}(162 \mathrm{MHz}$, $\left.\mathrm{C}_{6} \mathrm{D}_{6}\right): \delta[\mathrm{ppm}] 0.27(\mathrm{~m}),-7.24(\mathrm{~m})$. IR: v $\left(\mathrm{cm}^{-1}\right) 2961(\mathrm{~m})$,
2896 (m), 1794 (s, Ru-H), 1423 (m), 1271 (m), 923 (s), 853 (m), 705 (s), 695 (s). Analysis calculated for $\mathrm{C}_{12} \mathrm{H}_{38} \mathrm{P}_{4} \mathrm{Ru}(\%)$ : C, 35.38; H, 9.40. Found: C, 35.21, 9.20.

X-ray crystallography of compounds 1-OAc, 1-Et and 1Pr:

A suitable, single crystal was coated with oil, affixed to a glass capillary, and centered on the diffractometer in a stream of cold nitrogen. Reflection intensities were collected with a Bruker SMART CCD diffractometer, equipped with an LT-2 low-temperature apparatus, operating either at $100 \mathrm{~K}$ (1-OAc, 1-Pr) or at $193 \mathrm{~K}(\mathbf{1 - E t})$. Data were measured using $\omega$ scans of $0.3^{\circ}$ per frame for $30 \mathrm{~s}$ until a complete hemisphere had been collected. The first 50 frames were recollected at the end of the data collection to monitor for decay. Cell parameters were retrieved using SMART ${ }^{32}$ software and refined with SAINT $^{33}$ on all observed reflections. Data were reduced with SAINT, which corrects for Lp and decay. An empirical absorption correction was applied with SADABS. ${ }^{34}$ The structures were solved by direct methods with the SHELXS- $90^{35}$ program and refined by full-matrix least-squares methods on F2 with SHELXL-97, ${ }^{36}$ incorporated in SHELXTL Version $5.10 .^{37}$ The crystal of 1-Pr was pseudo-merohedrally twinned and required additional refinement using PLATON Version $61205 .^{38}$

\section{Acknowledgment}

This work was supported by grants from the Petroleum Research Fund (PRF\#36323-GB3) and Research Corporation (CC5065). In addition, we are grateful for funding from the National Science Foundation (CHE-9724458) for the purchase of an inert atmosphere glovebox. Support was also received from the Council on Undergraduate Research (EMN, made possible by the Merck Company Foundation). The authors would like to acknowledge Alfa Aesar for a gift of ruthenium chloride during the initial stage of the work. The authors wish to thank Amy Zweber, Dan Ferraro, Haosen Wang, and Adam Westman for experimental assistance. We are especially indebted to Michael Silver for his generous encouragement of this project.

\section{Appendix A. Supplementary material}

CCDC 1417001, CCDC 1417002, and CCDC 1427926 contain the supplementary crystallographic data for this paper. These data can be obtained free of charge from The Cambridge Crystallographic Data Centre via www.ccdc.cam.ac.uk/data_request/cif.

\section{Appendix B. Supplementary material}

Supplementary data related to this article can be found at http://dx.doi.org/10.1016/j.jorganchem.XXXXX.

\section{References}


[1] (a) Bergman, R. G. Nature 446 (2007) 391-193. (b) Labinger, J. A.; Bercaw, J. E. Nature 417 (2002) 507-514. (c) Crabtree, R. H. J. Organomet. Chem. 689 (2004) 4083-4091.(

[2] Elschenbroich, C. Organometallics. Wiley-VCH, Weinheim, Germany, 2006.

[3] (a) Bercaw, J. E.; Chen, G. S.; Labinger, J. A.; Lin, B.-L. J. Am. Chem. Soc. 130 (2008) 17654-17655. (b) Holtcamp, M. W.; Labinger, J. A.; Bercaw, J. E. J. Am. Chem. Soc. 119 (1997) 848-849.

[4] (a) Wick, D. D. and Goldberg, K. I. J. Am. Chem. Soc. 119 (1997) 10235-10236. (b) Kanzelberger, M.; Singh, B.; Czerw, M.; KroghJespersen, K.; Goldman, A. S. J. Am. Chem. Soc. 122 (2000) 11017-11018. (c) Desrosiers, P. J.; Shinomoto, R. S.; Flood, T. C. J. Am. Chem. Soc. 112 (1990) 704-713. (d) Vetter, A. J.; Rieth, R. D.; Brennessel, W. W.; Jones, W. D. J. Am. Chem. Soc. 131 (2009) 10742-10752. (e) Janowicz, A.; Bergman, R. G. . J. Am. Chem. Soc. 104 (1982) 352-354.

[5] (a) Northcutt, T. O.; Wick, D. D.; Vetter, A. J.; Jones, W. D. J. Am. Chem. Soc. (2001), 123, 7257-7270. (b) Jiao, Y.; Morris, J.; Brennessel, W. W.; Jones, W. D. J. Am. Chem. Soc. 135 (2013) 16198-16212.

[6] (a) Crumpton-Bregel, D. M.; Goldberg, K. I. J. Am. Chem. Soc. 125 (2003) 9442-9456. (b) Milstein, D. Acc. Chem. Res. 1984, 17, 221-226. (c) Gilbert, T. M.; Bergman, R. G. J. Am. Chem. Soc. 107 (1985) 93502-3507.

[7] Bernskoetter, W. H.; Kloek Hanson, S.; Buzak, S. K.; Davis, Z.; White, P. S.; Swartz, R.; Goldberg, K. I.; Brookhart, M. J. Am. Chem. Soc. 131 (2009) 8603-8613.

[8] (a) Stahl, S. S.; Labinger, J. A.; Bercaw, J. E. J. Am. Chem. Soc. 117 (1995) 9371-9372. (b) Wik, B. J.; Lersch, M.; Tilset, M. J. Am. Chem. Soc. 124 (2002) 12116-12117. (c) Vedernikov, A. N.; Fettinger, J. C.; Mohr, F. J. Am. Chem. Soc. 126 (2004) 11160-11161.

[9] (a) O'Reilly, S. O.; White, P. S.; Templeton, J. L. J. Am. Chem. Soc. 118 (1996) 5684-5689. (b) Canty, A. J.; Dedieu, A.; Jin, H.; Milet, A.; Richmond, M. K. Organometallics 15 (1996) 2845-2847.

[10] MacAdams, L.A.; Buffone, G. P.; Incarvito, C. D.; Golen, J. A.; Rheingold, A. L.; Theopold, K. H. Chem. Commun. (2003) $1164-1165$.

[11] (a) Hartwig, J. F.; Andersen, R. A.; Bergman, R. G. J. Am. Chem. Soc. 113 (1991) 6492-6498. (b) Mainz, V. V.; Andersen, R. A. Organometallics 3 (1984) 675-678.

[12] Kakiuchi, F. and Murai, S. Acc. Chem. Res. 35 (2002) 826-834.

[13] Statler, J. A.; Wilkinson, G.; Thornton-Pett, M.; Hursthouse, M. B. J. Chem. Soc., Dalton. Trans. (1984) 1731-1738.

[14] Jones, R. A.; Mayor Real, F.; Wilkinson, G.; Galas, A. M. R.; Hursthouse, M. B.; Abdul Malik, K. M. J. C. S. Dalton (1980) $511-518$.

[15] Wong, W.-K.; Chiu, K. W.; Statler, J. A.; Wilkinson, G.; Motavelli, M.; Hursthouse, M. B. Polyhedron 3 (1984) $1255-1256$.

[16] Mitchell, R. W.; Spencer, A.; Wilkinson, G. J. Chem. Soc., Dalton Trans. (1973) 846-854.

[17] Gusev, D. G.; Hübener, R.; Burger, P.; Orama, O.; Berke, H. J. Am. Chem. Soc. 119 (1997) 3716-3731.

[18] Mehrkhodavandi, P.; Schrock, R. R. J. Am. Chem. Soc. 123 (2001) 10746-10747.

[19] Reger, D. L.; Garza, D. G.; Lebioda, L. Organometallics 10 (1991) 902-906.

[20] Dahlenburg, L.; Frosin, K.-M. Polyhedron 12 (1993) 427-434.

[21] van der Bloom, M. E.; Higgitt, C. L.; Milstein, D. Organometallics 18 (1999) 2413-2419.

[22] Vela, J.; Vaddadi, S.; Cundari, T. R.; Smith, J. M.; Gregory, E. A.; Lachicotte, R. J.; Flaschenriem, C. J.; Holland, P. L. Organometallics 23 (2004) 5226-5239.

[23] Jiao, Y.; Evans, M. E.; Morris, J.; Brennessel, W. W.; Jones, W. D. J. Am. Chem. Soc. 135 (2013) 6994-7004.

[24] Alaimo, P. J.; Arndtsen, B. A.; Bergman, R. G. Organometallics 19 (2000) 2130-2143.

[25] Cummins, C. C.; Schaller, C. P.; Van Duyne, G. D.; Wolczanski, P. T.; Chan, A. W. E.; Hoffmann, R. J. Am. Chem. Soc. 113 (1991) 29852994.

[26] Fagnou, K.; Lautens, M. Angew. Chem. Int. Ed. 41 (2002) 26-47.

[27] Seyferth, D. Organometallics 28 (2009) 1598-1605.

[28] (a) Knorr, R.; Ruhdorfer, J.; Böhrer, P. Organpmetallics 34 (2015) 1038-1045. (b) Bruneau, A. M.; Liou, L.; Collum, D. B. J. Am. Chem. Soc. 136 (2014) 2885-2891.

[29] Hoffmann, R. W.; Brönstrup, M.; Müller, M. Org. Lett. 5 (2003) 313-316.

[30] Breitenfeld, j.; Ruiz, J.; Wodrich, M. D.; Hu, X. J. Am. Chem. Soc. 135 (2013) 12004-2891.

[31] Hoffman, P. R.; Caulton, K. G. J. Am. Chem. Soc. 97 (1975) 4221-4228.

[32] SMART Version 4.043 Software for the CCD Detector System, Bruker Analytical X-ray Systems: Madison, WI, 1995.

[33] SAINT Software for the CCD Detector System, Version 4.035; Bruker Analytical X-ray Systems: Madison, WI, 1995.

[34] SADABS program for absorption corrections using the Bruker CCD Detector System. Based on: Blessing, R. H. Acta Crystallogr., Sect. A 51 (1995) 33.

[35] G. M. Sheldrick. SHELXS-90, Program for the Solution of Crystal Structures; University of Göttingen: Göttingen, Germany, 1990.

[36] G. M. Sheldrick. SHELXL-97, Program for the Solution of Crystal Structures; University of Göttingen: Göttingen, Germany, 1997.

[37] SHELXTL 5.10 (PC Version); Siemens Analytical X-ray Instruments, Inc.: Madison, WI, 1998.

[38] A.L.Spek. PLATON, Utrecht University, Utrecht, The Netherlands, 2005. 


\section{${ }^{*}$ Graphical abstract}

$\mathrm{CH}_{3}$

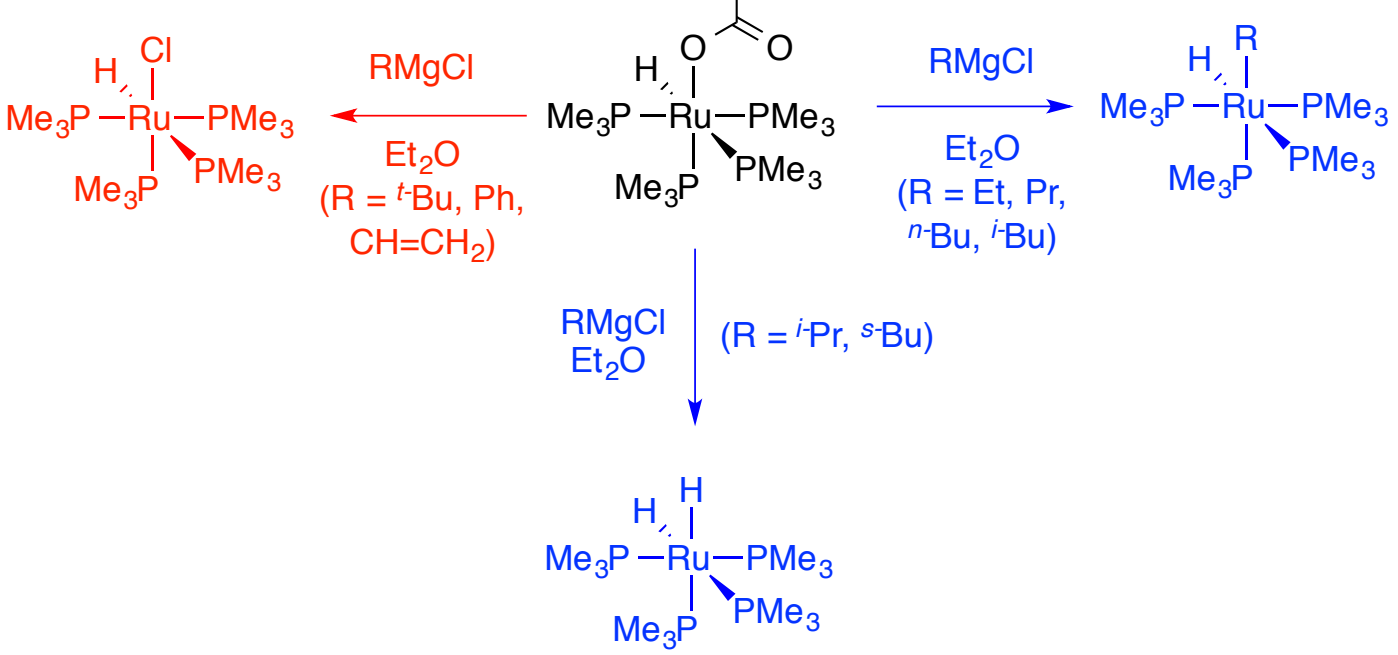

